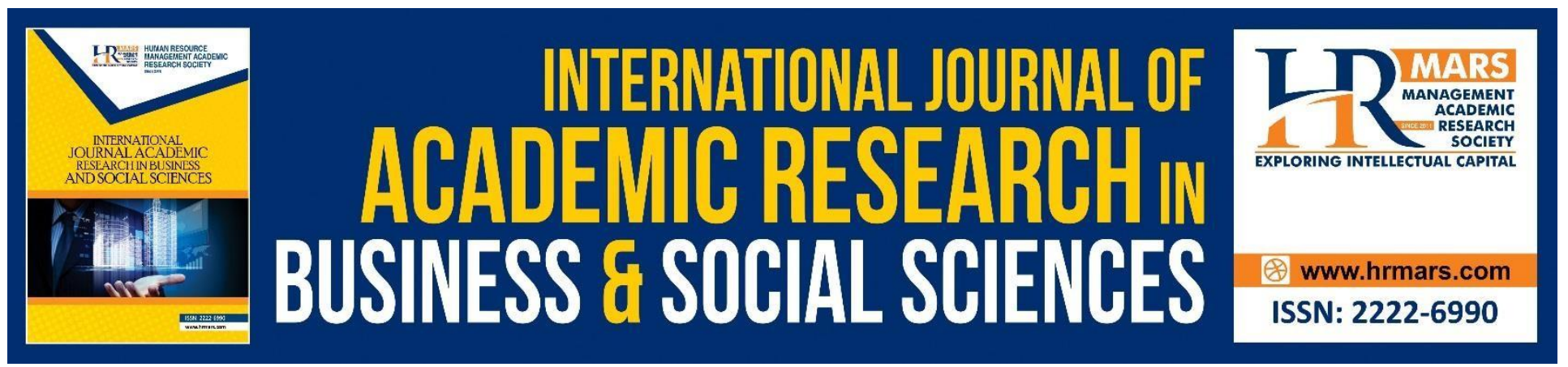

\title{
Brand Orientation in Small and Medium Enterprises (SMEs) from Malaysian Government Perspective
}

Samira Raki, Mahani Mohammad Abdu Shakur

To Link this Article: http://dx.doi.org/10.6007/IJARBSS/v8-i7/4375

DOI: $10.6007 /$ IJARBSS/v8-i7/4375

Received: 03 June 2018, Revised: 19 June 2018, Accepted: 29 June 2018

Published Online: 15 July 2018

In-Text Citation: (Raki \& Shakur, 2018)

ToCitethisArticle:Raki, S., \& Shakur, M.M. A.(2018).BrandOrientation inSmallandMediumEnterprises (SMEs) from Malaysian Government Perspective. International Journal of Academic Research in Business and Social Sciences, 8(7), 377-391.

\section{Copyright: () 2018 The Author(s)}

Published by Human Resource Management Academic Research Society (www.hrmars.com)

This article is published under the Creative Commons Attribution (CC BY 4.0) license. Anyone may reproduce, distribute, translate and create derivative works of this article (for both commercial and non-commercial purposes), subject to full attribution to the original publication and authors. The full terms of this license may be seen at: http://creativecommons.org/licences/by/4.0/legalcode

Vol. 8, No. 7, July 2018, Pg. 377 - 391

http://hrmars.com/index.php/pages/detail/IJARBSS

JOURNAL HOMEPAGE

Full Terms \& Conditions of access and use can be found at http://hrmars.com/index.php/pages/detail/publication-ethics 


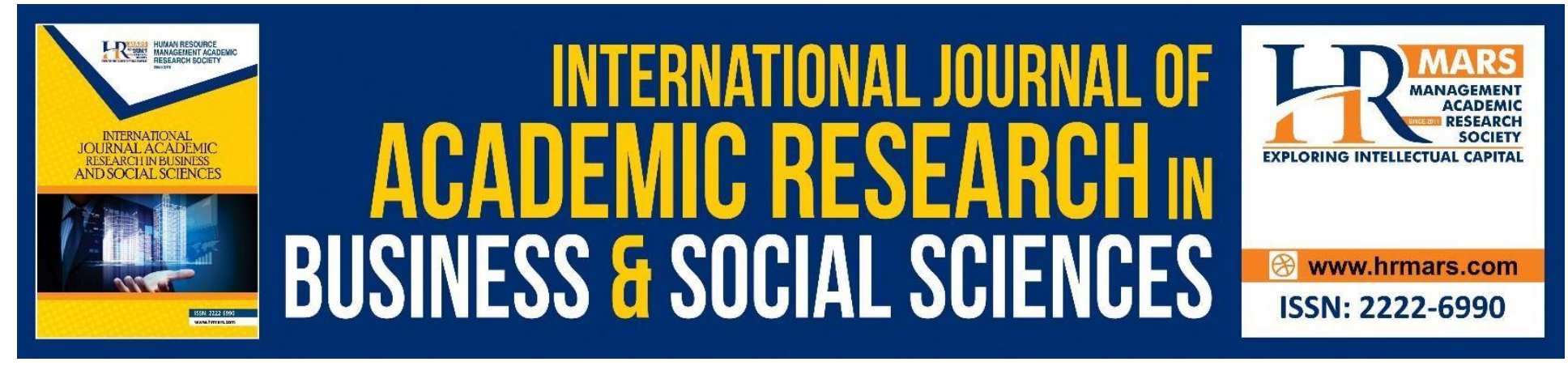

\title{
Brand Orientation in Small and Medium Enterprises (SMEs) from Malaysian Government Perspective
}

\author{
Samira Raki \\ Faculty of Economics and Business, Universiti Malaysia Sarawak, 94300, Kota Samarahan, Sarawak, \\ Malaysia, \\ Email: 15010180@siswa.unimas.my

\section{Mahani Mohammad Abdu Shakur} \\ Faculty of Economics and Business, Universiti Malaysia Sarawak, 94300, Kota Samarahan, Sarawak, \\ Malaysia, \\ Email: asmahani@unimas.my
}

\begin{abstract}
The purpose of this study is to develop a brand orientation model based on Malaysian SMEs context. Semistructured interviews were selected as the research method in order to get an expert opinion from Small and Medium Size Enterprise Corporation Malaysia (SME Corp) and Malaysia External Trade Development Corporation (MATRADE). Both agencies operate under Ministry of International Trade and Industry (MITI) to support SMEs and they were chosen for this study because they have long experience in promoting branding to SMEs. Four major levels of brand orientation have emerged from the data analysis: absent, low, medium, and high. This paper highlights the importance of branding for Malaysian SMEs and emphasizes the crucial issues related to the adoption of branding process and the solutions provided by Malaysian government to enhance brand development. This research is among the restricted works that have studied brand orientation from the governmental perspective and have proposed a related model. It suggests considering the proposed model and referring to SME Competitiveness Rating for Enhancement (SCORE) for future studies on branding in Malaysian SMEs.

Keywords: Brand, brand orientation, SMEs, managers, Government.

\section{Introduction}

SMEs play a vital role in improving economic dynamism. They constitute the majority of companies in developed and developing countries. SMEs contribute significantly to job creation, income growth, and poverty reduction (Erenkol \& Öztaş 2015). According to OECD (2017), structured SMEs in emerging markets make up $45 \%$ of total employment and $33 \%$ of Gross Domestic Product (GDP).

Despite the importance of SMEs for every economy's growth, a significant number of SMEs are still suffering to sustain in the market place (Cheng et al. 2014) and face multiple challenges in their quest
\end{abstract}


of success and growth. Several studies highlighted the high rate of SMEs failure especially in their first three years of existence (Abidin et al. 2014; Fatoki 2014; Ihua 2009). For instance, in Malaysia the number of small and medium firms has reduced from 17,157 in 2010 to 16,893 in 2011 (Abidin et al. 2014). In addition, a report from Komuniti Portal revealed that the failure rate among Malaysian SMEs was as high as $60 \%$ (as cited in Ahmad \& Seet 2009). Nevertheless, numerous solutions are offered to SMEs to overcome their growth obstacles including branding.

Considered as a survival strategy (Urde 1994) and as an effective competitive weapon (Baumgarth 2010; Spence \& Essoussi 2010; Urde 1994), it is generally believed that branding plays an important role in today's business environment. Urde (1994) added that the future of companies depends on brands. To get benefit from branding, firms need to be brand-oriented. Brand orientation is a brand-centred strategy (Baumgarth \& Schmidth 2010). However, even though brand orientation has emerged for over than two decades to challenge market-oriented approach (Anees-ur-Rehman et al. 2016), it is still a new paradigm at its infant stage (Baumgarth et al. 2013). Furthermore, few studies have been conducted on brand orientation from SMEs perspectives compared to large organizations (Centeno et al. 2013; Hirvonen et al. 2016; Reijonen et al. 2014; Spence \& Essoussi 2010; Wong \& Merrilees 2005). And consequently, limited studies have provided a brand orientation model explaining the different levels of brand orientation that SMEs go through. Moreover, very restricted researches have examined brand orientation from an external stakeholder perspective.

Hence, the objective of this paper is to develop a brand orientation model from a governmental position in order to deepen the understanding of brand orientation in SMEs. In this study, two primary Malaysian government's agencies were selected, namely SME Corp and MATRADE, as they interact and influence branding within SMEs through specific branding and marketing programs. The first section of this paper is a general review of prior research on brand orientation. The second section describes the process of data collection and analysis for this exploratory study. The following sections outline and discuss the findings. At the end, the paper concludes with managerial implications and future research.

\section{Brand Orientation Concepts' Definition}

Branding or brand management is an art of building, managing and improving a brand (Aaker 1996). It has attracted the intention of multiple practitioners and scholars (Urde 1994; Urde et al. 2013). For instance, branding management in China between 1994 and 2008 was among top 5 research topics (Wang 2012). Furthermore, brand management has emerged as a top management priority (Aaker et al. 2012; Keller \& Lehmann 2006; Knight et al. 2000). Several scholars have underlined the prominence of branding for firm's growth (e.g. Urde 1994; Odoom 2016; Gromark \& Melin 2011; Baumgarth 2010; Wong \& Merrilees 2005 2007). In addition, Birnik et al. (2010) emphasized that branding is the solution for Asian firms to get out of the commodity trap, compete at the international level, and improve their margins. However, to get benefit of branding, firms should be brand- oriented.

There are a few definitions of brand orientation (Reijonen et al. 2014). However, the concept of brand orientation was first introduced by Urde in 1994 (Anees-ur-Rehman et al. 2016; Anees-ur-Rehman 2014; Blamer 2013). According to Urde (1999) brand orientation is defined as: [. . .] "an approach in which the processes of the organization revolve around the creation, development, and protection of brand identity in an ongoing interaction with target customers with the aim of achieving lasting competitive advantage in the form of brands" (p.117). Furthermore, brand orientation could be 
INTERNATIONAL JOURNAL OF ACADEMIC RESEARCH IN BUSINESS AND SOCIAL SCIENCES

Vol. 8, No. 7, July 2018, E-ISSN: 2222-6990 @ 2018 HRMARS

considered as an inside-out approach where brand identity is a strategic central point (Urde et al. 2013). Moreover, Baumgarth (2010) added brand orientation is a specific form of marketing orientation translated by the high importance given by top management to branding activities; while Renton et al. (2016) described brand orientation as the level to which the brand is viewed.

\section{Brand Orientation in SMEs: Benefits, Challenges and Solutions}

From SMEs perspective, although Odoom et al. (2017) argued that branding strategies are not applicable to small firms, and Reijonen et al. (2014) suggested that brand orientation alone is not advantageous for SMEs in emerging economies; Balmer (2013) stated that many scholars have highlighted the importance of brand orientation. Furthermore, Renton et al. (2016) pointed out that a growing consensus emerges that SMEs with high level of brand orientation realize better financial results, regarding business context, firm size and knowledge. In addition, Baumgarth (2010) outlined those SMEs with weak brand orientation are at competitive disadvantage compared to big companies. Furthermore, Wong and Merrilees (2007) pointed out that brand-oriented firms get further benefits from their marketing strategies more than those which are not. Others stated that there is a positive relationship between branding and firm performance in general (Odoom 2016; Gromark \& Melin 2011; Baumgarth 2010; Wong \& Merrilees 2005 2007) and SME performance in particular (Asamoah 2014). For instance, studies undertaken by Renton et al. (2016) and Ahmad and Iqbal (2013) highlighted the positive impact of brand orientation on brand and consequently firm performance in food and beverage industry.

Despite the benefits outlined above, branding is still facing many challenges. Several studies have reported budget limitation as a major challenge affecting branding (Horan el al. 2011; Khalique el al. 2011; Khan \& Khalique 2014; Ojasalo et al. 2008; Wong \& Merrilees 2005); while other studies emphasized competition as a critical constraint (Birnik et al. 2010; Khan \& Khalique 2014). Furthermore, few studies have stressed the importance of owners-managers in influencing the course life of branding. Horan et al. (2011) pointed out that branding is dominantly under influence of managers-owners. Reijonen et al. (2014) put forward managers as central to understand their views towards market orientation. Roll (2013) and Birnik et al. (2010) argued that most of SMEs owners have short term trader mentality; whereas Spenser and Essoussi (2010) highlighted that brands are reflecting their owners-managers visions and values. Accordingly, there is a close association between brand personality and brand owner (Centeno et al. 2013). Therefore, the mindset is very crucial in defining and influencing SMEs brand orientation.

In order to support SMEs to overcome branding challenges and consequently become more brandoriented, Reijonen et al. (2014) suggested providing training and developing simple tools for those SMEs. However, multiple countries offer promotional policies to support SMEs to overcome potential obstacles and consequently succeed in their quest of growth and prosperity; for instance, India and China (Singh el al. 2009). In Malaysian context, Malaysian government also deploys significant efforts in supporting SMEs through the execution of its SME Master Plan 2012-2020 that envisions defining the policy direction of SMEs in all sectors. Therefore, this paper focus is on the investigation of brand orientation from the perspective of SMEs policy executive agencies: SME Corp and MATRADE.

\section{Brand Orientation Models}

Past researches have provided different brand orientation models, such as Baumgarth's model. This model suggests 4 constructs in formatting brand orientation, namely values, norms, artifacts, and behaviors and shows brand orientation has a positive effect on market and financial performance 
(Baumgarth 2010). However, Baumgarth's model was used in several studies (e.g. Renton et al. 2016; Anees-ur-Rehman 2014). On the one hand, Anees-ur-Rehman (2014) proposed 3 levels of brand orientation constructs, namely mindset, management, and performance and outlined that each level should be embedded into internal and external environments. On the other hand, Renton et al. (2016) supported Baumgarth's statement and extend on his model through consideration of contingency theory. They argued that industry factors influence the development of the four constructs suggested by Baumgarth; where brand values are of high importance in making strategies. Furthermore, another study by Balmer (2013) suggested that brand orientation includes four constructs: corporate brand orientation, product brand orientation, service brand orientation, and omni-brand orientation.

Different from the models described above that focused on brand orientation components, Wong and Merrilees (2005) have suggested three levels of branding orientation: minimalist, embryonic, and integrated. These three stages are "the most relevant for SMEs, starting with minimalist, then progressing to embryonic and finally to integrated" (p. 160). In line with the work of Wong and Merrilees (2005), this research intends to provide a model that explains the different levels of brand orientation according to Malaysian context. An exploratory study was undertaken to address this research aim.

\section{Research Methodology}

A qualitative approach was mainly selected in consideration of the exploratory nature of the research. There are limited studies related to brand orientation in Malaysian Context. According to Hirvonen et al. (2016), research on branding in SMEs is still at the infant stage. Moreover, Churchill (1991) considered a qualitative approach is more suitable for exploratory work investigating under- researched topics. Hence, in order to get an expert point view, semi-structured in-depth interviews were undertaken with the directors of two proficient government agencies located in Kuching (SME Corp and MATRADE).

\section{Data Collection Process}

SME Corp and MATRADE were contacted through emails containing details of the research. The interviews were carried out in their headquarters located in Kuching in English language. Each respondent provided the researchers with brief and enriching presentation of their organizations' goals and missions. Later on, a series of mainly open-ended questions took place in respect of the themes of the research defined based on the understanding from the literature review. This type of questions allows the participants to speak their minds and express their feelings openly and freely. The interview session with MATARDE was recorded using the mobile and took 70 minutes; while a note taking was used for the second interview with SME Corp and lasted 90 minutes. A report on brand development program was provided by SME Corp to enhance the understanding of the current situation of branding.

SME Corp was established in 1996 under the name of SMIDEC (Small and Medium Industries Development Corporation); it nurtures domestic businesses and help them to be more competitive. Once an SME reaches a relevant level of performance and is interested in exporting, it has the choice to join MATRADE. MATRADE is Malaysia's national trade promotion and marketing agency; it started operating in March 1993. It aims to assist firms (i.e. SME and Non-SME) to enter international markets. Considered as sister agencies by MITI and operating under its jurisdiction, SME Corp and MATARDE provide companies with financial assistance. The choice of these sister agencies is 
motivated by the fact that Malaysia is going toward a high-income nation as stated in 2020 vision which has put SMEs at the central stage of policy makers' interest.

Formulations of interview questions

The interview questions were formulated around three major themes namely, (1) state-of-the-art of brand orientation; (2) brand orientation main challenges and solutions; and (3) the perception of Malaysian products and the future of brand orientation. These themes were drawn from the literature and were based on the objectives set for the research. Accordingly, the questions were formulated as follow:

Q1. Do Malaysian SMEs consider branding?

Q2. On a scale of 1 to 10 , how many SMEs are aware of the importance of branding? Q3. What kind of branding has been considered by the Malaysian SMEs?

Q4. What are the challenges that Malaysian SMEs are facing in terms of branding?

Q5. What are the solutions offered by your organization to overcome branding challenges? Q6. What is your perception of "Made in Malaysia" products?

Q7. How do you see branding in five years?

\section{Data Analysis and Validation}

The interviews sessions were structured around the three themes described above which made data analysis and interpretation easy for the researchers. A thematic content analysis of the interviews and the document provided by SME Corp was undertaken to identify the key answers to the selected themes of interviews. A comparison process was conducted to determine the similarities and differences in the analyzed data. The interview of final results and analysis were given to the participants to guarantee that the gathered data were valid. This process is known as member checking. A consent form was also handed to the participants to get their agreement on the findings and the publication.

\section{Findings and Discussion}

Theme 1: State-of-the-art of brand orientation

Q1. Do Malaysian SMEs consider Branding?

The directors of MATRADE and SME Corp pointed out that most of Malaysian SMEs are not fully aware of the importance of branding; they are more market-oriented instead. However, both of the directors emphasized that there is an improvement in terms of positive attitude towards branding compared to past decades.

Q2. On a scale of 1 to 10 , how many SMEs are aware of the importance of branding?

On a scale of 1 to 10, the director of SME Corp considered that 4 out of 10 of SMEs value brands due to the fact they are medium-to-well established firms (at least 2 years of existence). The director of SME Corp stated that among those $40 \%$, only $15 \%$ do have real brand management process. In general, they are those SMEs with 3 stars and above according to SCORE1 rating system. 6 out of 10 SMEs are instead more market-oriented. They believe that branding costs money and consumes time.

1 SCORE is a diagnostic tool to rate and enhance competitiveness of SMEs based on their performances and capabilities. Created by SME Corp, SCORE ranges from 0 to 5 stars. SMEs from 0 to 2 stars are considered as basic business operators. SMEs with a score from 3 and above have some degree of sophistication and can be prepared for export. 
However, the director of MATRADE highlighted that $40 \%$ of SMEs are not aware of the prominence of branding while the other $60 \%$ do consider branding but with limitations of resources and mindset. Based on the above answers, this study finds out that a significant number of Malaysian SMEs across all sectors have no awareness of the importance of branding; while few of them do consider branding with limitations of resources, time and mindset. This finding is in line with the literature which considers that SMEs pay little attention to the importance of branding compared to large organizations (Centeno et al. 2013; Spence \& Essoussi 2010; Reijonen et al. 2014). The above results show differences in percentage given to the level of awareness of SMEs managers: MATARADE director considers that $60 \%$ are fully aware of the importance of branding; while SME Corp general manager assumes that only $40 \%$ of SMEs managers who are fully mindful of the prominence of branding.

The disparities in numbers are justified by the fact that even though both agencies work closely, they do not deal with the same data base. In other words, SME Corp deals with all segments of SMEs with SCORE ranging from 0 to 5 stars. However, MATRADE which aims to promote the export has an upgraded type of SMEs starting from 3 stars (in most cases those which have benefited from SME Corp programs).

This paper outcome has led to identify four Malaysian SMEs brand orientation based on their level of awareness of branding importance and their scoring number (See table 1). The SCORE stands as a successful tool to rate SMEs performance. According to Premalatha (2013), SCORE has become the pride of SME Corp since it has received requests from several countries (i.e. UK, Japan, South Korea...) to study SCORE system and to replicate it for their SMEs.

Table 1: Malaysian SMEs brand orientation typology based on score rating system and SMEs level of awareness of branding

\begin{tabular}{|c|c|c|c|c|}
\hline \multicolumn{2}{|c|}{$\begin{array}{l}\text { Classification according to SME } \\
\text { Corp }\end{array}$} & \multicolumn{3}{|c|}{ Classification according to authors' findings } \\
\hline $\begin{array}{l}\text { Score } \\
\text { rating }\end{array}$ & SME characteristics & Brand awareness & Brand orientation & Brand activities \\
\hline $0-2$ & $\begin{array}{l}\text { Very basic with } \\
\text { manual/semi-automated } \\
\text { processes }\end{array}$ & Lack of awareness & Absent & $\begin{array}{l}\text { Trading mindset } \\
\text { (sales } \\
\text { and } \\
\text { turnover) and lack } \\
\text { of promotion }\end{array}$ \\
\hline 3 & $\begin{array}{l}\text { Semi to fully automated } \\
\text { Able to implement quality } \\
\text { system and undertake } \\
\text { product and } \\
\text { process } \\
\text { improvements }\end{array}$ & $\begin{array}{l}\text { Aware but not } \\
\text { investing or } \\
\text { investing a little in } \\
\text { branding }\end{array}$ & Low to Medium & $\begin{array}{r}\text { Packaging } \\
\text { and } \\
\text { networking }\end{array}$ \\
\hline 4 & $\begin{array}{l}\text { Fully automated } \\
\text { Invest in process } \\
\text { /product/improvements }\end{array}$ & $\begin{array}{l}\text { Aware and } \\
\text { investing } \\
\text { branding }\end{array}$ & Medium to High & $\begin{array}{l}\text { Brand } \\
\text { management } \\
\text { process }\end{array}$ \\
\hline 5 & $\begin{array}{l}\text { High level of automated } \\
\text { Good branding / packaging }\end{array}$ & $\begin{array}{l}\text { Investing } \\
\text { branding }\end{array}$ & High & $\begin{array}{l}\text { Brand } \\
\text { management } \\
\text { process }\end{array}$ \\
\hline
\end{tabular}


These four classifications are named in ascending order as follows: Absent brand orientation, low brand orientation, medium brand orientation, and high brand orientation. An SME with a score ranging from 0 to 2 stars, it is not mindful of the importance of branding, and has consequently low marketing activities and accordingly an absent brand orientation. It is focusing basically on setting up its products and strengthening its products quality. In other words, it has a trading mindset as described by Birnik et al. (2010). Nevertheless, an SME with 3 stars is considered as a low to medium brand-oriented firm. It is aware of the benefits of branding but yet still struggling regarding limitations of resources and time. Therefore, this type of SME is still thinking short term profit and yet investing more on packaging and networking to communicate its brand. An SME with 4 stars has a medium to high level of awareness and therefore it is more brand-oriented with brand management practices. Finally, an SME with five stars is strongly brand oriented and consequently considering branding as long-term strategy and possesses a strong brand management processes which is translated to day- to-day branding activities.

Consequently, as illustrated in figure 1, an SME with high level of awareness of branding and/or with high number of SCORE is more brand-oriented.

\section{Figure 1: 3-D Brand orientation model from SME Corp and MATRADE perspective}

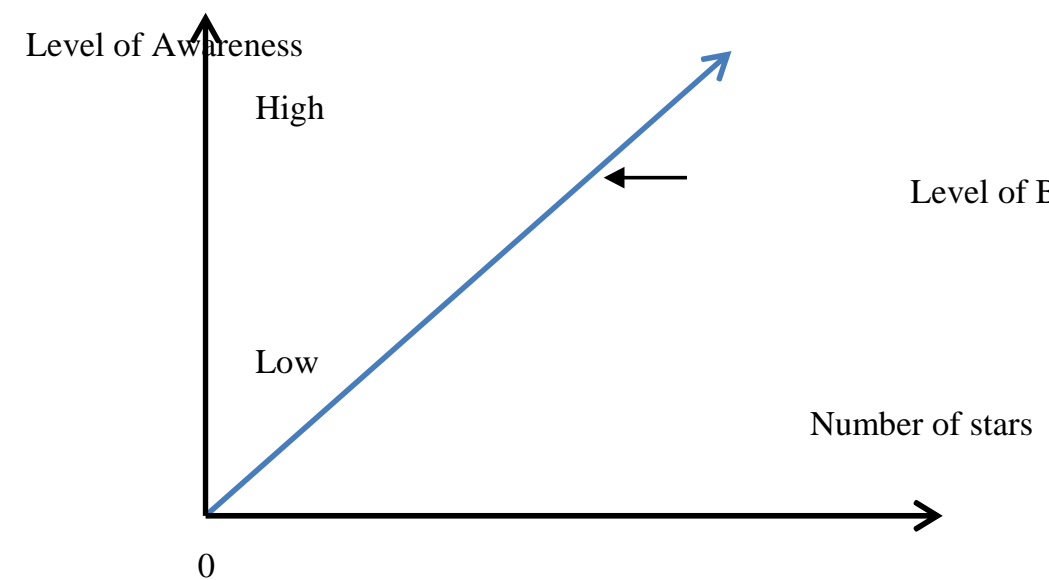

In contrast with Wong and Merrilees (2005) brand orientation proposed model, this study has focused on describing the current situation of brand orientation from the perspective of MATRADE and SME Corp. Hence, four brand orientation levels were proposed (absent, low, medium and high). Q3. What kind of branding has been considered by the Malaysian SMEs?

Both directors stressed out that most of SMEs consider branding at the product level. The director of SME Corp added that the choice of type of branding depends on firms' sector and size; but in general, most of SMEs go for product branding instead of corporate branding. This outcome is explained by the fact that SMEs manager were more market oriented before considering branding and therefore they want the consumer to put their focus on products rather than the company. The literature has cited many advantages to product branding; such as flexibility in terms of allowing companies to position itself in different market segments (Xie \& Boggs 2006), and being subject to less reputation damage (McDonald et al. 2001). 
The first theme of research aimed to state the current situation of brand orientation in Malaysian SMEs from the standpoint of SME Corp and MATRADE. A brand orientation model was proposed in contrast with literature findings. The model highlights four levels of brand orientation ranging from absent to high. On the one hand, an absent to low brand-oriented SME has a trade mentality and focuses on short term profits. On the other hand, a medium to high brand-oriented SME possesses brand management processes. The next theme discusses the constraints faced by SMEs in terms of brandings and the solutions offered by SME Corp and MATRADE.

\section{Theme 2: Brand orientation main challenges and proposed solutions}

Q4. What are the challenges that Malaysian SMEs are facing in terms of branding?

Both directors pointed out the mindset as the main challenge that is holding Malaysian SMEs from investing in branding. Most of SMEs owners do not consider branding as effective for their business growth because they are more market-oriented. This outcome is supported by several studies. Horan et al. (2011) and Reijonen et al. (2014) illustrated that small firms' managers have major influence on branding process; which it referred to as "mindset" by both directors of SME Corp and MATRADE. Moreover, Birnik et al. (2010) stated that most of SMEs owners have short term trader mentality. In other words, they are profit-oriented. The second main issue facing SMEs in considering branding is the financial issues. Literature studies support this statement. Works by Horan et al. (2011), Khan and Khalique (2014), Khalique et al. (2011), Ojasalo et al. (2008), and Wong and Merrilees (2005) all considered budget restriction as major challenge faced by SMEs in their business growth. Competition whether domestic or international has emerged as the third major challenge as stated by both directors. This constraint was raised by several studies (e.g. Cheng et al. 2014; Birnik et al. 2010; Khan \& Khalique 2014).

Q5. What are the solutions offered by your organization to overcome branding challenges? Intensive trainings programs and workshops proposed by both agencies stand as major solutions to overcome mindset problem. For instance, SME Corp offers specific branding development program under the name of "SME- Brand Development Program", with the purpose of improving branding position in SMEs. Likewise, MATRADE offers Mid-Tier Companies Development Program (MTCDP). MTCDP is a tailored program that aims to enhance the visibility of SMEs brands. Moreover, MATRADE director stresses the importance of branding in every possible event or workshop. On the one hand, this finding is in line with Reijonen et al. (2014) suggestion; which state that training programs and development of simple tools as very important to support SMEs. On the other hand, this outcome disagrees with a study undertaken by Khan and Khalique (2014) that considered that SMEs in Malaysia lack of training programs. This difference could be explained by the fact that SMEs do not make the effort to look for appropriate programs. Furthermore, both general managers highlight the financial support as another determinant solution provided to SMEs. For instance, SME Corp offers branding development program that provides $50 \%$ of financial support. To date, hundreds of companies have profited from this program. However, both directors state that their financial support could not benefit to all SMEs. As for competition the third major challenge, both agencies provide SMEs with the knowledge and information they need to compete domestically and internationally.

This second theme concludes that SMEs are facing three major challenges when considering branding, namely mindset, budget restriction and competition. However, SME Corp and MATRADE propose intensive programs and workshop to support SMEs. Moreover, both agencies provide 
INTERNATIONAL JOURNAL OF ACADEMIC RESEARCH IN BUSINESS AND SOCIAL SCIENCES

Vol. 8, No. 7, July 2018, E-ISSN: 2222-6990 @ 2018 HRMARS

financial support and required information to compete at national and international level. The next section is about the perception of Malaysian products and the future of branding.

Theme 3: Perception of Malaysian products and future of branding

Q6. What is your perception of "Made in Malaysia" products?

Both organizations' directors assumed that "Made in Malaysia" has a good position in terms of product quality and consumer's perception. However, it is not strong enough to compete regionally with Japan and South Korea, and therefore internationally. Furthermore, MATRADE general manager stressed out that during overseas visits of international fairs and meeting with delegations from abroad, a positive attitude have been noticed from abroad companies towards Malaysian products. However, the same overseas firms complained about packaging that is not at the same quality level as the Japanese and the South Korean. Packaging is a powerful communication tool for the products and brand (Abidin et al. 2014) as it influences consumers into buying the product (Lew \& Sulaiman 2013). Therefore, both directors stated that they emphasize the importance of packaging whenever they meet with SMEs.

Q7. How do you see branding in 5 years?

Both agencies have strong beliefs that Malaysian SMEs perception of branding will improve in the next 5 coming years. This positive attitude is motivated by the increasing number of programs, workshops, and efforts deployed by both agencies in order to enhance the level of awareness of the importance of branding for the survival of these SMEs.

\section{Conclusion}

The literature survey and the results of the study highlight that branding in most Malaysian SMEs receives little or no attention despite the growing number of policy makers programs made specifically for the matter. This study considers four types of SMEs in terms of branding orientation depending on their level of awareness and their scoring received by SME Corp: absent, low, medium, and high. Furthermore, it outlines the importance of government policy executives MATRADE and SME Corp as key stakeholders in formatting brand orientation. Fully aware of the main barriers of branding namely, managers' mindset, budget restriction and competition, both agencies (MATRADE and SME Corp) empower SMEs with adequate programs and financial assistance to overcome those obstacles and to become more competitive. From theoretical viewpoint, this paper is among the limited studies that have looked at brand orientation from SME Corp and MATRADE views and have proposed a related model. This paper suggests that SMEs manager should consider branding as a crucial strategy for their survival and collaborate with MATARDE and SME Corp for their growth. It is recommended that future research on brand orientation in SMEs should take into consideration the proposed brand orientation model and refer to SCORE rating system offered by SME Corp to decide on the typology of the SMEs to study.

\section{Acknowledgment}

The authors would like to show their gratitude to both directors of SME Corp and MATRADE for their full and fructuous collaboration and for providing insights, expertise, and trustworthy information that greatly assisted and guided the research. 
INTERNATIONAL JOURNAL OF ACADEMIC RESEARCH IN BUSINESS AND SOCIAL SCIENCES

Vol. 8, No. 7, July 2018, E-ISSN: 2222-6990 @ 2018 HRMARS

\section{References}

Aaker, D. A. (1996). Measuring brand equity across products and markets. California management review, 38(3), 102-120.

Aaker, D. A., \& Joachimsthaler, E. (2012). Brand leadership. Simon and Schuster.

Abidin, S. Z., Effendi, R. A. A. R. A., Ibrahim, R., \& Idris, M. Z. (2014). A Semantic Approach in Perception for Packaging in the SME's Food Industries in Malaysia: A Case Study of Malaysia Food Product Branding in United Kingdom. Procedia-Social and Behavioral Sciences, 115, 115-130.

Ahmad, N., \& Iqbal, N. (2013). The impact of market orientation and brand orientation on strengthening brand performance: An insight from the beverage industry of Pakistan. International review of management and business research, 2(1), 128.

Ahmad, N.H., Seet. P.S. Dissecting Behaviours Associated with Business Failure: A Qualitative Study of SME Owners in Malaysia and Australia. Small Business Economics, 5(9), 98-104.

Anees-ur-Rehman, M. (2014). Clarifying the Brand Orientation Construct for Business-to- Business Sector. International Journal of Business and Management, 9(12), 62-73.

Anees-ur-Rehman, M., Wong, H. Y., \& Hossain, M. (2016). The progression of brand orientation literature in twenty years: A systematic literature review. Journal of Brand Management, 23(6), 612630.

Asamoah, E. S. (2014). Customer based brand equity (CBBE) and the competitive performance of SMEs in Ghana. Journal of Small Business and Enterprise Development, 21(1), 117-131.

Balmer, J., T. (2013). Corporate brand orientation: What is it? What of it?. Journal of Brand Management, 20, (9), 723-741.

Baumgarth, C. (2010). Living the brand: brand orientation in the business-to-business sector. European Journal of Marketing, 44(5), 653-671.

Baumgarth, C. \& Schmidt, M. (2010). How strong is the business-to-business brand in the workforce? An empirically-tested model of 'internal brand equity' in a business-to-business setting. Industrial Marketing Management, 39 (8), 1250-1260.

Baumgarth, C., Merrilees, B. \& Urde, M. (2013). Brand orientation: past, present, and future. Journal of Marketing Management, 29 (9-10), 973-980.

Birnik, A., Birnik, A., \& Sheth, J. (2010). The branding challenges of Asian manufacturing firms. Business Horizon, 53, 523-532.

Centeno, E., Hart, S. \& Dinnie, K. (2013). The five phases of SME brand-building. Journal of Brand Management, 20(6), 445-457.

Cheng, W. H., Kadir, K. A., \& Bohari, A. M. (2014). The strategic planning of SMEs in Malaysia: a view of external environmental scanning. International Journal of Business and Society, 15(3), 437. 
INTERNATIONAL JOURNAL OF ACADEMIC RESEARCH IN BUSINESS AND SOCIAL SCIENCES

Vol. 8, No. 7, July 2018, E-ISSN: 2222-6990 @ 2018 HRMARS

Churchill, G., A. (1991). Marketing research: Methodological foundations. Fort Worth., TX: Dryden Press.

Erenkol, H. A. D., \& Öztaş, Y. B. B. (2015). Entrepreneurial Brand. Procedia-Social and Behavioral

Sciences, 195, 1138-1145

Fatoki, O. (2014). The Causes of the Failure of New Small and Medium Enterprises in South Africa. Mediterranean Journal of Social Sciences, 5(20), 922-927.

Gromark, J., \& Melin, F. (2011). The underlying dimensions of brand orientation and its impact on financial performance. Journal of Brand Management, 18(6), 394-410.

Hirvonen, S., Laukkanen, T., Salo. J. (2016). Does brand orientation help B2B SMEs in gaining business growth? Journal of Business \& Industrial Marketing, 31(4), 472-487.

Horan, G., O'Dwyer, M. \& Tiernan, S. (2011). Exploring management perspectives of branding in service SMEs. Journal of Services Marketing, 25(2), 114-21.

Ihua, U. B. (2009). SMEs Key Failure-Factors: A Comparison between the United Kingdom and Nigeria. Journal of Social Science, 18(3), 199-207.

Khalique, M., Shaari, J. A. N., Isa, A. H. Md., \& Ageel, A. (2011). The challenges faced by the small and medium enterprises (SMEs) in Malaysia: in intellectual capital perspective. International Journal of current research, 3(6), 398-401.

Khan, M., W., \& Khalique, M. (2014). An Overview of Small and Medium Enterprises in Malaysia and Pakistan: Past, Present and Future Scenario, 2(2), 38-49.

Keller, K.L \& Lehmann, D.R, (2006). Brands and Branding: Research findings and future priorities. Marketing Science, 25(6), 740-759.

Knight, R. F., \& Pretty, D. J. (2000). A survey of brand risk management. Journal of Brand Management, 7(5), 353-365.

Lew, S., \& Sulaiman, Z. (2014). Consumer Purchase Intention toward Products Made in Malaysia vs. Made in China: A Conceptual Paper. Procedia-Social and Behavioral Sciences, 130, 37-45.

McDonald, M.H., de Chernatony, L. \& Harris, F. (2001). Corporate marketing and service brands- Moving beyond the fast-moving consumer goods model, European Journal of Marketing, 35(3/4), 335-352.

Odoom, R., \& Odoom, R. (2016). Brand-building efforts in high and low performing small and mediumsized enterprises (SMEs). Journal of Small Business and Enterprise Development, 23(4), 1229-1246. 
INTERNATIONAL JOURNAL OF ACADEMIC RESEARCH IN BUSINESS AND SOCIAL SCIENCES

Vol. 8, No. 7, July 2018, E-ISSN: 2222-6990 @ 2018 HRMARS

Odoom, R., Odoom, R., Narteh, B., Narteh, B., Boateng, R., \& Boateng, R. (2017). Branding in small- and medium-sized enterprises (SMEs) Current issues and research avenues. Qualitative Market Research: An International Journal, 20(1), 68-89.

OECD. (2017). Enhancing the contributions of SMEs in a global and digitalised economy. OECD Publishing, Paris.

Ojasalo, J., Natti, S. \& Olkkonen, R. (2008). Brand building in software SMEs: an empirical study. Journal of Product and Brand Management, 17(2), 92-107.

Premalatha, J. (2013, September 18). Why SME Corp is proud of its SCORE. Retrieved from http://www.thesundaily.my.

Reijonen, H., Párdány, S., Tuominen, S., Laukkanen, T., Komppula, R. (2014). Are growth-oriented SMEs more likely to adopt market and brand orientations?. Journal of Small Business and Enterprise Development, 21(2), 250-265.

Renton, M., Daellenbach, U., Davenport, S., \& James, E, R. (2016). Finding fit: An exploratory look at SME brand orientation and brand management in the New Zealand food and beverage sector. Journal of Brand Management, 1-17.

Roll, M. (2013). China branding: opportunities and challenges. Business Strategy Series, 9(5), 231-237.

Singh, R., K., Garg, S., K., \&Deshmukh, S.G. (2009). The competitiveness of SMEs in a globalized economy Observations from China and India. Management Research Review, 33(1), 54-65.

Spence, M. \& Essoussi, L.H. (2008). SME brand building and management: an exploratory Study. European Journal of Marketing, 44 (7/8), 1037-1054.

Urde, M. (1994). Brand Orientation - A Strategy for Survival. Joumal of Consumer Marketing. 11(3), 1832.

Urde, M. (1999), "Brand orientation: a mindset for building brands into strategic resources", Journal of Marketing Management, 15 (1-3), 117-33.

Urde, M., Baumgarth, C., \& Merrilees, B. (2013). Brand orientation and market orientation - From alternatives to synergy. Journal of Business Research, 66(1), 13-20.

Wang, C. L. (2012). Handbook of Contemporary Marketing in China: Theories and Practice. Nova Science Publishers, Inc.

Wong, H.Y. \& Merrilees, B. (2005). A brand orientation typology for SMEs: a case research approach. Journal of Product and Brand Management, 14(3), 155-162. 
INTERNATIONAL JOURNAL OF ACADEMIC RESEARCH IN BUSINESS AND SOCIAL SCIENCES

Vol. 8, No. 7, July 2018, E-ISSN: 2222-6990 @ 2018 HRMARS

Wong, H. Y., \& Merrilees, B. (2007). Closing the marketing strategy to performance gap: the role of brand orientation. Journal of Strategic Marketing, 15(5), 387-402.

Xie, H. Y., \& Boggs, D. J. (2006). Corporate branding versus product branding in emerging markets. Marketing Intelligence \& Planning, 24(4), 347-364. 